\title{
GROUND LEVEL OZONE EFFECTS IN INDIVIDUAL GROWTH PHASES OF CENTRAL EUROPEAN SUBMOUN- TAIN BEECH FORESTS
}

\author{
DANIELA KELLEROVÁ, RASTISLAV JANÍK
}

The Institute of Forest Ecology of the Slovak Academy of Sciences, Štúrova 2, 96053 Zvolen, The Slovak Republic; e-mail: kellerova@savzv.sk

\begin{abstract}
Kellerová D., Janík R., 2013. Ground level ozone effects in individual growth phases of Central European submountain beech forests. Ekológia (Bratislava), Vol. 33, No. 1, p. 93-100, 2014.

We observed ground level ozone concentrations on a series of five beech experimental plots, one representing the original stand and the other four generated and modified by cuts of graduated intensity. The study was carried out in a beech ecosystem in the Kremnické vrchy Mts, the Western Carpathian region, in years 1999-2008. The plots, established in 1989, were evaluated and compared statistically before and after the cutting modification in 2004. The level of significance of the effect of this intervention was $99 \%$ on the plot representing small-area clear-cut and on the plot treated with medium cut. Differences, though not significant, were also found in the other plots. Apart from the effects due to the stocking reduction, the whole post-intervention period was characterised with the influence of progressively increasing average air temperatures and similarly increasing ozone concentrations. Globally, the ozone concentrations on all plots were lower (average value $39 \mathrm{\mu g} \mathrm{m}^{-3}$ ) during the period 1999-2003 than in the following years 2004-2008 (average value $55 \mathrm{~g} \mathrm{~m} \mathrm{~m}^{-3}$ ). Maximum values measured in the growing season ranged from 36 to $140 \mu \mathrm{g}$ $\mathrm{m}^{-3}$. The allowable limit exceeded 10 times in years 1999-2003 but 17 times in years 2004-2008, implying worsening conditions in Central European beech forest stands.
\end{abstract}

Key words: ground level ozone, forest beech, forest harvesting, reforestation, Western Carpathian.

\section{Introduction}

One of the cardinal environmental problems in Central Europe is the occurrence of episodes with high ground level ozone concentrations adversely affecting all components of living environment (Bytnerowicz et al., 2002; Muzika et al., 2004; Karlsson et al., 2007; Sanz et al., 2007; EEA, 2010). Agents promoting ozone formation are mono-nitrogen oxides $\left(\mathrm{NO}_{x}\right)$ and volatile organic compound (VOC) emissions, high air temperature, high solar radiation, cloudless days and frosts (Castell et al., 2008; Šec et al., 2007). More frequently occurring are periods of extreme drought on the one hand and, torrential rains and floods on the other. Ozone has adverse destructive effects on vegetation, and also on broadleaf and coniferous trees (Šach, Černohous, 2005), by affecting biochemical processes in plant assimilatory or- 
gans and by lowering their photosynthetic rate. The first symptom of damage is, in general, a loss of chlorophyll manifested through chlorosis, later through drying of plant tissues (Mikkelsen et al., 1995). The leaf area is reduced, and so is assimilation. Then follows reduction of internodia number and length, and reduction of leaf number and size. The structure of above-ground plant parts is modified. Limited vital functions may have adverse affects on plant root systems and on the ecosystem's stability as a whole. Apart from natural and anthropogenis factors, the stability of ecosystems is influenced by their structure and composition, by management ways or interventions into stand development and by stand regeneration processes. Woody plants in ecosystems are fixed to their site for 100 or more years, so the factors influencing forests in the individual phases of their growth are necessary to recognise and regard. The goal of our research was to indicate and statistically evaluate ozone concentrations over time (10 years) and over space across environmentally differentiated conditions (beech stands diversified by cutting in management process).

\section{Material and methods}

Our study ran on a series of monitoring plots in a beech ecosystem in the Kremnické vrchy Mts $\left(\varphi=48^{\circ} 38^{\prime} 10^{\prime \prime} \mathrm{N}, \lambda\right.$ $=19^{\circ} 04^{\prime} 08^{\prime \prime} \mathrm{E}$ ), of the Western Carpathian region, in years 1999-2008. The monitoring plots, five in number, were generated by shelterwood cutting interventions with graduated intensity, in the year 1989. The original stand (OS) is without any intervention either at the establishment of series or since then. The dominant woody plant on this plot is beech (Fagus sylvatica L.), with a cover of $94.7 \%$. The other four plots created by cutting in February (Greguš, 2007) represented a small-area clear-cut (SC), heavy cut (HC), medium cut (MC) and light cut (LC). The second shelterwood stocking-modifying cut-series was applied in spring 2004 (Barna, 2008). Details about the stand modification on particular plots are provided in Table 1 . The stands on these plots were progressively naturally regenerated, according to the physiological, light, temperature and other conditions.

$\mathrm{T}$ a b l e 1. Change of stocking density and growth dynamics of a beech stand series on research plots in the Kremnické vrchy Mts.

\begin{tabular}{|l|lll|}
\hline Stands modified by cutting & $\begin{array}{l}1989 \text { after the first } \\
\text { intervention }\end{array}$ & $\begin{array}{l}\text { 2004 before the second } \\
\text { intervention }\end{array}$ & $\begin{array}{l}\text { 2004 after the second } \\
\text { intervention }\end{array}$ \\
\hline Small-area clear-cut & 0.0 & Small pole stage & Thicket \\
Heavy cut & 0.3 & $0.5^{*}$ & $0.0^{* *}$ \\
& Mature stand & Rotation maturity & Small pole stage \\
Medium cut & 0.5 & $0.7^{*}$ & 0.3 \\
Original stand & Mature stand & Rotation maturity & Rotation maturity \\
& 0.9 & $1.0^{*}$ & 1.0 \\
Light cut & Mature stand & Mature stand & Mature stand \\
& 0.7 & $0.9^{*}$ & 0.5 \\
& Mature stand & Rotation maturity & Rotation maturity \\
\hline
\end{tabular}

*Barna 2008

${ }^{*}$ In the second intervention in year 2004, the plot generated with heavy intervention in 1989 was not a clear-cut with respect to the parent stand, as at that time there had been created a natural understorey (small-pole stage).

The plots with dominant beech are situated at spacing of 50-110 m (Fig. 1) on a slope at 480-510 m a.s.l. The slope is west-facing, with an inclination of 30 to $36 \%$ (Schieber, 2007). In 1989 (first cutting intervention), the stand age was $80-90$ years. 


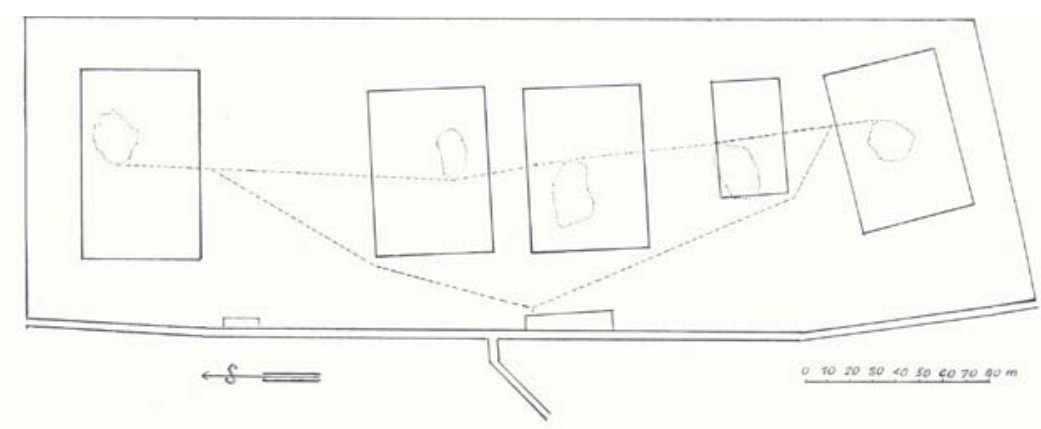

SC - small - area clear - cut, HC - heavy cut, MC - medium cut, OS - original stand, LC - light cut

Fig. 1. Layout of experimental plot series in the Kremnické vrchy Mts, Central Europe, in 1989 the first cutting intervention.

The climate in the Kremnické vrchy Mts is moderately warm and moderately humid. The long-term mean annual air temperature is $8.2^{\circ} \mathrm{C}$, and in the growing season $14.9^{\circ} \mathrm{C}$. The annual total precipitation ranges from 510 to $1040 \mathrm{~mm}$, and in the growing season from 160 to $530 \mathrm{~mm}$ (Kellerová, Dubová, 2002; Janík, 2006).

Creating respectively, degree of ground level ozone formation is a very complex process. Horizontal formation takes place with the assistance of precursors from European sources, vertical from the free troposphere, and from natural sources (isoprenes, terpenes from forests). The monitoring plots are not under direct impact of pollutants nor are they extremely influenced by pollution from remote sources. At a closer distance, three stationary energyproducing units are situated in the Zvolenská kotlina basin: an industrial park, a system of highways and a railway crossing. Under appropriate weather situation (anticyclones), these units can cause airborne pollution to the plots. The input of airborne pollution into the Kremnické vrchy Mts is discussed in Dubová, Bublinec (2006) and in Janík et al. (2011).

The effects of ozone on submountain beech forests were evaluated by the alternative method of passive samplers. Identification of ground level ozone concentrations in localities technically less accessible but vulnerable to airborne-pollutants can possibly be done using the manual sorption-accumulation method proposed by Werner (Werner, 1991; Hangartner et al., 1996; Werner et al., 1999). Ozone concentration is given in standard units of ppb or in converted $\mu \mathrm{g} \mathrm{m}^{-3}$ per day. From the daily values, we calculated the annual characteristics. The measurements were carried out in summer, from April to September, at regular intervals (from 7 to 10 days). Passive ozone collectors are placed on each face of two parallel, of $1.5 \mathrm{~m}$ above the surface. Operation is simple and the results obtained are comparable with continuous analyzers (Cox, 2003; De Vries et al., 2003; Bytnerowicz et al., 2004). The disadvantage of this method is that it does not follow the 24 -hour $\mathrm{O}_{3}$ concentrations. The stands have fully developed leaves generally from May and maintain them to the end of growing season in September (Schieber, 2006). More details about the method are provided in Kellerová (2002). In 2004, the second intervention was accomplished into the stands, so the samplers were removed and no measurement was performed over the whole growing season of 2004 .

Statistical characteristics of measure and position were calculated and the tests were performed using the software package Statistica v 7. The normalness of distribution was tested with the ShapiroWilk W test. The significance of differences of basic sets among the monitoring plots was evaluated with the Student's t-test for independent variables. The results were also verified using the software package Statgraphics.

\section{Results and discussion}

The basic aim of this research was to investigate differences in ground level ozone concentrations among several stand types growing in very similar conditions but differentiated by their stocking density, a small-area clear-cut included. 
The first research period covering years 1999-2003 shows relatively stable stand conditions, thanks to the absence of cutting interventions for 10-15 years. In this period, the dynamics of stands development was driven by multiple ecological and site factors acting in synergy. The mean ozone concentrations measured on the plots in the growing season ranged from 8 to $92 \mu \mathrm{g} \mathrm{m}^{-3}$. The average ozone concentrations measured at European Monitoring and Evaluation Programme (EMEP) and the regional stations on the territory of Slovakia in those years ranged from 49 (in 1999) to $65 \mu \mathrm{g} \mathrm{m}^{-3}$ in 2003 (SHMÚ, 2010).
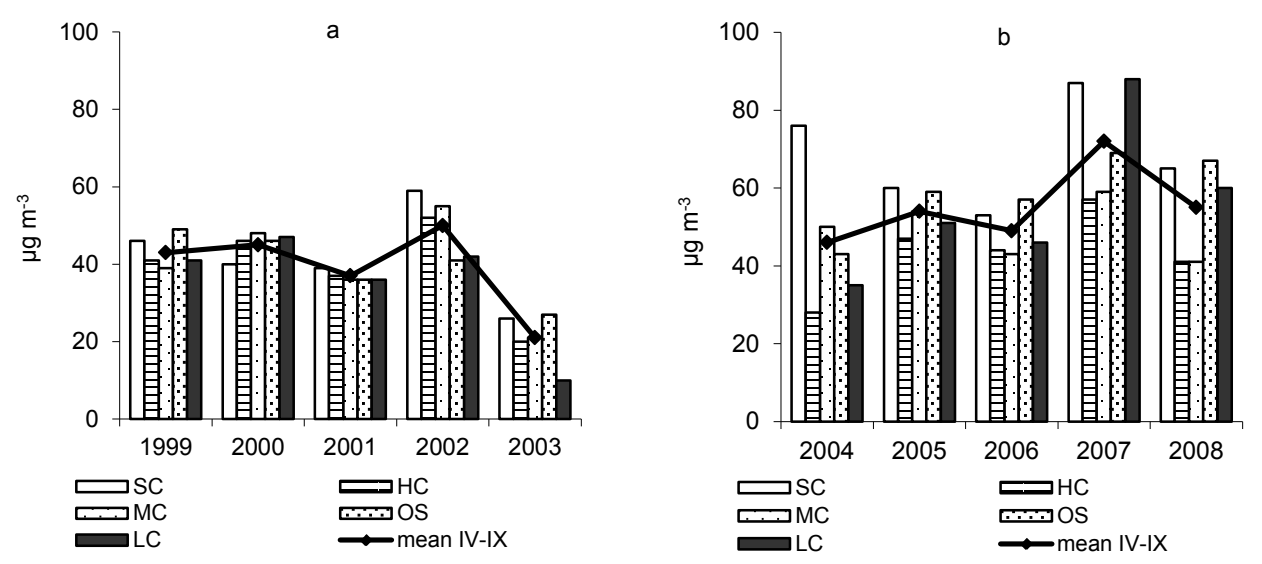

Fig. 2. Ozone concentrations on research plots between 1999 and 2003 (a) and after the second clear-cut between 2004 and 2008 (b). SC - small-area clear-cut, HC - heavy cut, MC - medium cut, OS - original stand, LC - light cut.

Individual differences in ground level ozone concentrations observed in this five-year period followed similar courses on all plots (Fig. 2a). This fact has also been confirmed by statistical testing of differences between the mean annual ozone concentrations within individual plots where these differences were found insignificant.

Conversely, the impact of management intervention in 2004 was evident on the smallarea clear-cut and on the plot with medium cut, at a 99\% significance level. Very close dependence of ozone concentration on cutting intervention, with a correlation coefficient of 0.94, was confirmed on the plot with medium intervention. On the other plots, the cutting impact was not confirmed at such high significance level.

In general, the ozone concentrations in years 1999-2003 were lower on all plots (mean value $39 \mathrm{\mu g} \mathrm{m}^{-3}$ ) than in the next period 2004-2008 with the mean concentration representing $55 \mu \mathrm{g} \mathrm{m}^{-3}$. On almost all plots, these values manifested by $5-10 \%$ more variability before than after the cutting intervention (Table 2).

In years 2004-2008, the highest mean ozone concentrations were measured in year 2007: $87 \mu \mathrm{g} \mathrm{m}^{-3}$ on the small-area clear-cut and $88 \mu \mathrm{g} \mathrm{m} \mathrm{m}^{-3}$ on the plot with light cut (Fig. 2b). Apart from the modified density, influence of mean temperatures was expressed in this period, manifesting a progressive increase almost over the whole period. While the mean annual temperature in 2005 was $7.9^{\circ} \mathrm{C}$, in 2008 it was $9.7^{\circ} \mathrm{C}$. The highest mean summer tempera- 
T a b le 2. Descriptive statistics of ground level ozone concentrations in the Kremnické vrchy Mts in years 1999-2008.

\begin{tabular}{|c|c|c|c|c|c|}
\hline Plots & SC & $\mathrm{HC}$ & $\mathrm{MC}$ & $\mathrm{OP}$ & $\mathrm{LC}$ \\
\hline \multicolumn{6}{|c|}{ Before cutting in year 2004} \\
\hline Valid & 5 & 5 & 5 & 5 & 5 \\
\hline Mean & 42 & 39.2 & 39.8 & 39.8 & 35.2 \\
\hline Minimum & 26 & 20 & 21 & 27 & 10 \\
\hline Maximum & 59 & 52 & 55 & 49 & 47 \\
\hline Range & 33 & 32 & 34 & 22 & 37 \\
\hline Standard deviation & \pm 11.9 & \pm 12.1 & \pm 12.9 & \pm 8.7 & \pm 14.6 \\
\hline Standard error & 5.4 & 5.4 & 5.8 & 3.9 & 6.5 \\
\hline Coefficient of variation $\%$ & 28.3 & 30.9 & 32.4 & 21.9 & 41.5 \\
\hline \multicolumn{6}{|c|}{ After cutting in year 2004} \\
\hline Valid & 5 & 5 & 5 & 5 & 5 \\
\hline Mean & 68.2 & 43.4 & 49.4 & 59 & 56 \\
\hline Minimum & 53 & 28 & 41 & 43 & 35 \\
\hline Maximum & 87 & 57 & 59 & 69 & 88 \\
\hline Range & 34 & 29 & 18 & 26 & 53 \\
\hline Standard deviation & \pm 13.4 & \pm 10.5 & \pm 7.5 & \pm 10.2 & \pm 20.0 \\
\hline Standard error & 6 & 4.7 & 3.4 & 4.6 & 8.9 \\
\hline Coefficient of variation \% & 19.5 & 24.2 & 15.2 & 17.3 & 35.7 \\
\hline
\end{tabular}

ture values were recorded in 2007: $20.4^{\circ} \mathrm{C}$ in July and $19.7^{\circ} \mathrm{C}$ in August. In this year, the highest values of ground level ozone concentrations were also measured, ranging from 57 to $88 \mu \mathrm{g} \mathrm{m}^{-3}$. Similar concentrations were measured at the same time in identical altitude areas in the Czech Republic (Hůnová et al., 2012). The average ozone concentrations measured at EMEP and the regional stations on the territory of Slovakia in those years ranged from 59 (in 2004) and $62 \mu \mathrm{g} \mathrm{m}^{-3}$ in 2007 (SHMÚ, 2011).

For the Central European submountain and high-mountain areas, two ozone maxima in a year are typical (Kremler, 2002; Bytnerowicz et al., 2004). The first one usually occurs in spring (April, May), the second in summer (July, August). These maxima are mostly episodes with very high ozone concentrations considered as more dangerous for woody plants than long periods with only slightly elevated concentrations (Mortensen et al., 1995). Maximum values measured in April-September varied from 36 to $140 \mu \mathrm{g} \mathrm{m}^{-3}$, which is typical for the summer throughout Central Europe (Fig. 3). The number of extreme ozone events, exceeding the allowable limit (24-hour mean concentration of $65 \mu \mathrm{g} \mathrm{m}^{-3}$ for vegetation 92/72/EC), in the years from 1999 to 2003 was 10 and in the years from 2004 to 2008 went up to even 17.

Some high mean values of ozone concentration recorded on the plots mean that beyondlimit concentrations may have been persisting in the stands for several days, as the mean daily temperature was calculated from samples exposed in the field for a week. Appealing is the fact that under such extreme situation, ozone damage to vegetation may generate in course of a few hours.

Despite several extreme situations in years 1999 and 2003, the ozone concentration values did not differ much among the plots in this period: The highest values, representing $22 \%$ of 
Fig. 3. Maximum ozone concentrations on experimental plots in summer (April-September) in years 1999-2008 compared to the ecological limit for vegetation $65 \mu \mathrm{g} \mathrm{m}^{-3}$. SC - small-area clear-cut, HC heavy cut, MC - medium cut, OS - original stand, LC - light cut.

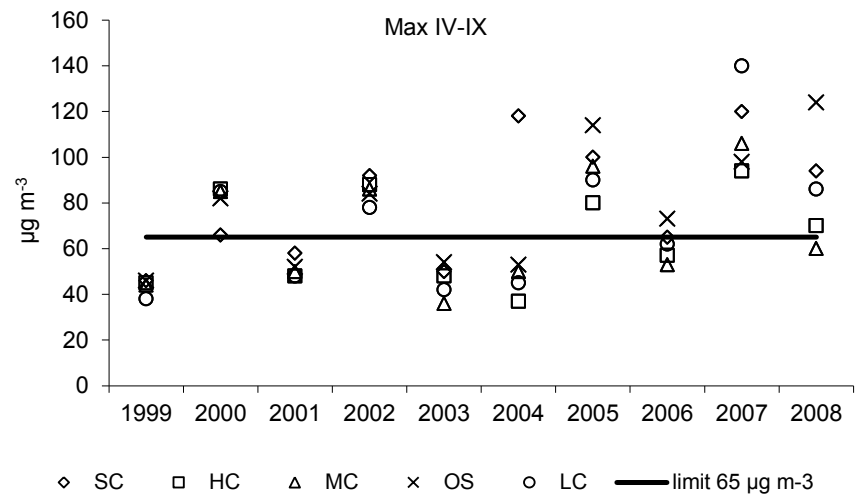

Mean 1999-2003

Mean 2004-2008
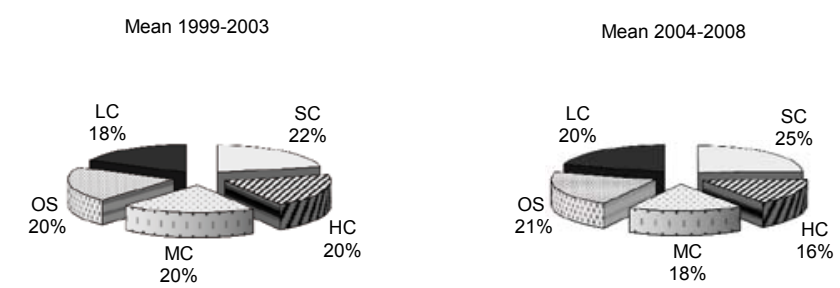

Fig. 4. Percentage of ground level ozone concentration in beech stands differentiated by shelterwood cuts between 1999 and 2003 and between 2004 and 2008.

SC - small-area clear-cut, HC heavy cut, MC - medium cut, OS - original stand, LC - light cut.

the total amount deposed on all plots, were systematically recorded on the small-area clearcut covered with a thicket 10-15 years after the establishment cutting. The woody plants in the thicket stage are the least resistant against ozone damage. The lowest concentrations (18\%) were recorded on the plot treated with light cutting intervention (Fig. 4).

After the second intervention, in years 2004-2008, the highest ozone concentrations $(25 \%)$ were again measured on the small-area clear-cut. The lowest value, $16 \%$, was obtained on the plot established by heavy cut, on which all trees in 2004 were in rotation maturity, and as such were removed. At that time, however, the plot had been already covered with forest stand at small-pole stage. After the modification in 2004, some, but not many, trees in rotation maturity were left on the plots established by medium and by light shelterwood cut (Table 1). The former small-area clear-cut, covered in 2004 by a thicket, showed ozone concentration values very similar to the values in the original parent stand without intervention. The higher ozone concentrations in the mature forest stand and in the young, developing forest (thicket) may be, theoretically, different from anthropogenic and natural factors (air temperature and humidity etc.), due to emissions (VOCs) of isoprenes and terpenes - well-known ozone precursors. The forests are the dominant source.

\section{Conclusion}

The ground level ozone measurements performed over 10 years on monitoring plots with graduated stocking density in the Kremnické vrchy Mts have delivered a large piece of data 
about $\mathrm{O}_{3}$ generated in the growing season, from April to September. The changes in ozone concentrations were evident after removing additional trees from the stands, according to the forest management plan. The influence of management intervention on ground level ozone concentration was also concluded as being associated with temperature change recorded recently. It means that, especially in years 2004-2008, ground level ozone concentrations were increasing due to the increasing mean air temperature.

Over the whole research period, the concentration values were systematically highest on the plot where is was last mined in 1989, is formed new forest stand and in the study period was in the thicket stage.

Adverse fact for Central European beech growths is that, the number of overruns between 1999 and 2003 was 10, and in the period 2004-2008 went to an extreme of up to 17.

From the results of research to see that conditions for the formation of ground level ozone at the same time on the areas with varied intensity stocking may be different, what is the most showed and statistically confirmed in the years following immediately after the management intervention.

\section{Acknowledgements}

This work was supported by the Scientific Grant Agency of the Ministry of Education of the Slovak Republic and the Slovak Academy of Sciences (Projects No. 2/0089/14, 2/0027/13). We also acknowledge D. Kúdelová for preparing the English text.

\section{References}

Barna, M. (2008). The effects of cutting regimes on natural regeneration in submountain beech forests: species diversity and abundance. J. For. Sci., 54, 533-544.

Bytnerowicz, A., Godzik, B., Fraczek, W., Grodzinska, K., Krywult, M., Badea, O., Barancok, P., Blum, O., Cerny, M., Godzik, S., Mankovska, B., Manning, W., Moravcik, P., Musselman, R., Oszlanyi, J., Postelnicu, D., Szdzuj, J., Varsavova, M. \& Zota M. (2002). Distribution of ozone and other air pollutants in forests of the Carpathian Mountains in central Europe. Environ. Pollut., 116, 3-25. DOI: 10.1016/S0269-7491(01)00187-7.

Bytnerowicz, A., Godzik, B., Grodzinska, K., Frączek, W., Musselman, R., Manning, W., Badea, O., Popescu, F. \& Fleischer P. (2004). Ambient ozone in forest of Central, Eastern European mountains. Environ. Pollut., 130, 5-16. DOI: 10.1016/j.envpol.2003.10.032.

Castell, N., Mantilla, E. \& Millan M.M. (2008). Analysis of thropospheric ozone concentration on a Western Mediterranean site: castellon (Spain). Environ. Monit. Assess., 136, 3-11. DOI: 10.1007/s10661-007-9723-1.

Cox, R.M. (2003). The use of passive sampling to monitor forest exposure to $\mathrm{O}_{3}, \mathrm{NO}_{2}, \mathrm{SO}_{2}$ : a review and some case studies. Environ. Pollut., 126, 301-311. DOI: 10.1016/S0269-7491(03)00243-4.

De Vries, W., Reinds, G.J., Posch, M., Sanz, M.J., Krause, G.H.M., Catalayud, V., Renaud, J.P., Dupouey, J.L., Sterba, H., Vel, E.M., Dobbertin, M., Gundersen, P. \& Voogd J.C.H. (2003). Intensive monitoring of forest ecosystems in Europe. Brussels: UNECE, FIMCI.

Dubová, M. \& Bublinec E. (2006). Evaluation of sulphur and nitrate-nitrogen deposition to forest ecosystem. Ekológia (Bratislava), 25, 366-376.

EC (1992). Council Directive 92/72/EC. Official Journal of the European Communities, Commission of the European Communities, L 297, 1-4.

EEA (2010). Air quality in Europe - report. Copenhagen: EEA.

Greguš, C. (2007). Silvicultural systems in long-term of forestry in Slovakia (in Slovak). Zvolen: ÚEL SAV, NLC Zvolen.

Hangartner, M., Kirchner, M. \& Werner H. (1996). Evaluation of passive methods for measuring ozone in the European Alps. Analyst, 121, 1269-1272. DOI: 10.1039/AN9962101269. 
Hůnová, I. \& Schreiberová M. (2012). Ambient ozone phytotoxic potential over the Czech forests as assessed by AOT 40. iForest, 5, 153-162 [online 2012-06-25] URL: http://www.sisef.it/iforest/contents? id=ifor0617-005

Karlsson, P.E., Tang, L., Sundberg, J., Chen, D., Lindskog, A. \& Pleijel H. (2007). Increasing risk for negative ozone impacts on vegetation in northern Sweden. Environ Pollut., 150, 96-106. DOI: 10.1016/j.envpol.2007.06.016.

Kellerová, D. \& Dubová M. (2002). The hydrogen ion deposition and proton load of the Kremnické vrchy Mts. Ekológia (Bratislava), 21, 423-430.

Kellerová, D. (2002). Surface ozone at the beech ecological experimental station Kremnické vrchy Mts. Ekológia (Bratislava), 21, 26-32.

Kremler, M. (2002). Daily and annual course of surface ozone concentrations at Slovak monitoring stations. Meteorologický Časopis, 5, 29-36.

Janík, R. (2006). Characteristic of air temperature in beech ecosystem. Silva Balcanica, 7, 69-75.

Janík, R., Schieber, B., Bublinec, E. \& Dubová M. (2011). Content concentration $\mathrm{SO}_{4}^{2-}$ in soil water and throughfall in submountain beech ecosystems. Beskydy, 4(1), 9-18.

Mikkelsen, T.N., Dodell, B. \& Lütz C. (1995). Changes in pigment concentration and composition in Norway spruce induced by long-term exposure to low levels of ozone. Environ. Pollut., 87, 197-205. DOI: 10.1016/02697491(94)P2607-B.

Mortensen, N., Bastrup-Birk, A. \& Ro-Poulsen H. (1995). Critical levels of $\mathrm{O}_{3}$ for wood production of European beech (Fagus sylvatica L.). Water, Air Soil Pollut., 85, 1349-1354. DOI: 10.1007/BF00477169.

Muzika, R.M., Guyette, R.P., Zielonka, T. \& Liebhold A.M. (2004). The influence of $\mathrm{O}_{3}, \mathrm{NO}_{2}$ and $\mathrm{SO}_{2}$ on growth of Picea abies and Fagus sylvatica in the Carpathian Mountains. Environ. Pollut., 130, 65-71. DOI: 10.1016/j. envpol.2003.10.021

Sanz, M.J., Calatayud, V. \& Sanchez-Peña G. (2007). Measures of ozone concentration using passive sampling in forests of South Western Europe. Environ. Pollut., 145, 620-628. DOI: 10.1016/j.envpol.2006.02.031.

SHMÚ (2010). Evaluation of air quality in Slovak Republic 2009. Bratislava.

SHMÚ (2011). Evaluation of air quality in Slovak Republic 2010. Bratislava.

Schieber, B. (2006). Spring phenology of European beech (Fagus sylvatica L.) in submountain beech forest stand with various stocking between 1995-2004. J. For. Sci., 52, 208-216.

Schieber, B. (2007). Changes of flowering phenology of six herbal species in a beech forest (Central Slovakia): A decade analysis. Pol. J. Ecol., 55(2), 233-244.

Šach, F. \& Černohous V. (2005). Ground-level ozone and potential influence on declining experimental Norway spruce plantation in immission region of the Orlické vrchy Mts., Czech Republic. In M. Saniga (ed.). Súčasné otázky pestovania lesa. Zborník referátov (pp. 101-106). Zvolen: TU Zvolen.

Šec, K., Skácel, F., Malec, L. \& Tekáč V. (2007). Study of factors initiating the origin and extinction of tropospheric ozone (in Czech). Chemické Listy, 101, 1051-1057.

Werner, H. (1991). Methodische Details für das Ozonmonitoring mit Indigopapieren. II Workshop zum Thema Integrale Messmethoden (pp.1-110). Salzburg: AGRE ALP, AGRE ALPEN-AGRIA.

Werner, H., Kirchner, M., Welzl, G. \& Hangartner M. (1999). Ozone measurements along vertical transects in the Alps. Environmental Science and Pollution Research, 6, 83-87. DOI: 10.1007/BF02987554. 